\title{
DIABETES MELLITUS: GENERATING ISSUES FOR THE TEACHING OF BIOCHEMISTRY
}

\author{
Rodrigo Maciel Lima', Fernanda Rangel'1, Manoela Guimarães ${ }^{1}$, Valéria Marcelino ${ }^{1}$ \\ ${ }^{1}$ Instituto Federal Fluminense, Laboratório de Biologia (Rio de Janeiro, Brasil) \\ Supported by: IFF Campus Campos-Centro
}

INTRODUCTION: Current education has been grounded on traditional teaching practices; in other words, learning is regarded as an accumulation of knowledge given by the teachers. Use of resources such as videos and games can raise the interest of teachers since they are an attractive and less traditional alternative. Nevertheless, the use of generating issues stands out as it may help teachers to develop contextualized lessons. According to Freire (1987), this is the starting point in the process of constructing knowledge, replacing traditional practices and questioning the student's previous knowledge of Biochemistry. OBJECTIVES: Thus, the aim of this study was to prepare and present a lesson to a 12th grade class at IF Fluminense on carbohydrates, diabetes mellitus, and isomerism based on the theme "Diabetes Mellitus". MATERIALS AND METHODS: In order to collect data and check the validity of the use of such methodology in classes of Biochemistry, we used procedures such as: presentation of a video made by the authors about diabetes, a styrofoam model of a hepatic cell and biscuit models to show its metabolic functioning regarding metabolism of carbohydrates, styrofoam and toothpick molecular models aimed at explaining isomerism among main hexoses and, to finish the process, a roulette game named "Spinning with Biochemistry", adapted from the television show Roda a Roda Jequiti, presented by SBT network. In addition, students had a class based on the "Three Pedagogical Moments" methodology proposed by Delizoicov et al. (2007). DISCUSSION AND RESULTS: After this, students developed more grounded scientific concepts, making use of terms common in scientific language. This suggests that the use of a Generating Issues, in a class based on problem-solving methods supported by playful strategies, was a meaningful contribution to improve the understanding of scientific knowledge. CONCLUSION: This type of class grounded on less traditional practices can foster student motivation which, in turn, can result in more meaningful learning.

Keywords: generating issues; Carbohydrates; Isomerism 